\title{
On Benevolence and Love of Others ${ }^{1}$
}

\author{
Gabriella Slomp \\ University of St Andrews
}

Hobbes is famous for his insights into the impact of man's fear, glory and greed on war and peace, not for his views on the bearing of men's benevolence on the commonwealth. Are Hobbesian people even capable of love of others? In the literature, we find two main answers: one view is that Hobbes ruled out the possibility of disinterested benevolence among men; the other is that Hobbes considered actions driven by genuine benevolence possible but uncommon.

After reviewing in broad outlines the two above positions, this chapter seeks to demonstrate that Hobbes did not consider it relevant to establish if men are capable of genuine benevolence or not, because he maintained that the impact on peace of disinterested and self-interested benevolence is potentially the same: benevolent men can be as inept as egoists in differentiating apparent and real good for themselves and their loved ones, and the effect of misguided altruism on the commonwealth is as damaging as the effect of ill-advised egoism.

The chapter proceeds in steps: first, I consider Butler and Hume's different appraisals of Hobbesian benevolence, then I review the arguments one encounters in twentieth century scholarship for and against the occurrence of genuine benevolence in Hobbesian man; finally, I put forward my own understanding and appraisal of Hobbesian benevolence.

\footnotetext{
${ }^{1}$ I am very grateful to S.A. Lloyd for thorough and illuminating feedback on an earlier draft of this chapter. I wish also to thank Camillo Lamanna for constructive criticisms and copyediting. All remaining errors and stylistic infelicities are my own.
} 
When organising interpreters into different camps, there is always the danger that one acts as Procrustes, stretching or amputating interpretations so that they fit the iron beds prepared for them. In my overview of the two different positions on Hobbesian benevolence, I do not make the Procrustean claim that the quotations or observations that illustrate those positions overlap precisely with the core ideas of the interpreters who have voiced them. For example, I have only offered to John Watkins and David Gauthier accommodation in one camp, even though they do share a number of views with the other.

\section{Joseph Butler and David Hume on Hobbesian Benevolence}

Hobbes made some statements suggesting he was ambivalent about benevolence. On the one hand, he speaks of 'the love men bear to one another, or the pleasure they take in one another's company' (Elements, I. Chapter 9.16, p 43), and he includes the 'desire of good to another, Benevolence' (Leviathan, 6.22) among the passions of man and gives benevolence some prominence by listing it ahead of 'desire of riches, Covetousness'. On the other hand, throughout his writings Hobbes makes remarks that rule out the occurrence of disinterested benevolence among men. For instance:

The only reason why something appeals to or is craved by a person is that it benefits him, self-advantage being the proper and sufficient object of the will (Anti-White 487)

We grieve over the loss of riches and of friends because we feel ourselves deprived of the potential and of the protection that have raised our hopes of advancement (AntiWhite 465).

There is yet another passion, sometimes called love, but more properly good will or CHARITY. There can be no greater argument to a man, of his own power, than to find himself able not only to accomplish his own desires, but also to assist other men in theirs: and this is that conception wherein consisteth charity (Elements, I.9.17, p 44)

So clear is it from experience to anyone who gives any serious attention to human behaviour, that every voluntary encounter is a product either of mutual need or of the pursuit of glory; hence when people meet, what they are anxious to get is either an 
advantage for themselves or what is called $\varepsilon v \delta o \kappa \imath \mu \varepsilon \imath v$ which is reputation and honour among their companions. (Citizen Chapter 1.2. p23)

For no man giveth but with intention of good to himself, because gift is voluntary; and of all voluntary acts, the object is to every man his own good; of which if men see they shall be frustrated, there will be no beginning of benevolence or trust, nor consequently of mutual help, nor of reconciliation of one man to another. (Leviathan XV 16)

For people always have been, and always will be, ignorant of their duty to the public, as never meditating anything but their particular interest; (Behemoth, Dialogue I, p39)

Hobbes's ambivalence has given rise to very different interpretations of the nature of

Hobbesian benevolence. Reflecting on the above cited passage from Elements of Law, Bishop

Butler made the following famous comment:

Suppose a man of learning to be writing a grave book upon human nature, and to show in several parts of it that he had an insight into the subject he was considering: amongst other things, the following one would require to be accounted for; the appearance of benevolence or good-will in men towards each other in the instances of natural relation, and in others (Hobbes of Human nature Ch IX Sec 17). Cautious of being deceived with outward show, he retires within himself to see exactly, what that is in the mind of man from whence this appearance proceeds; and upon deep reflection, asserts the principle in the mind to be only the love of power, and delight in the exercise of it. (Butler [1726] 1969, footnote 1 to Section 6, p 18).

Butler, then, reads Hobbes as saying that men are self-seeking and incapable of disinterested benevolence, and that what appears to be good-will in human relations is in fact always driven by selfish motives. In his essay of 1967, Bernard Gert identifies Butler as the writer who gave 'greatest impetus' to the attribution to Hobbes of 'psychological egoism', which in Gert's definition holds that people never act to benefit others $(1969,111)$.

A different take on Hobbesian benevolence appears in the work of David Hume. In Appendix II to An Enquiry Concerning the Principles of Morals, Hume distinguishes between a principle 'which is utterly incompatible with all virtue or moral sentiment' and that he described thus:

This principle is, that all benevolence is mere hypocrisy, friendship a cheat, public spirit a farce, fidelity a snare to procure trust and confidence; and that while all of us, at bottom, pursue only our private interest, we wear these fair disguises, in order to 
put others off their guard, and expose them the more to our wiles and machinations. (Hume 1970, 295)

and another principle 'somewhat resembling the former', according to which:

whatever affection one may feel, or imagine he feels for others, no passion is, or can be disinterested; that the most generous friendship, however sincere, is a modification of self-love; and that, even unknown to ourselves, we seek only our own gratification, while we appear the most engaged in schemes for the liberty and happiness of mankind. By a turn of imagination, by a refinement of reflection, by an enthusiasm of passion, we seem to take part in the interests of others, and imagine ourselves divested of all selfish considerations: but, at bottom, the most generous patriot and most niggardly miser, the bravest hero and most abject coward, have, in every action, an equal regard to their own happiness and welfare. (Hume 1970, 296)

Hume notes that the latter principle 'has been the foundation of many system', and in the modern period can be found in the works of philosophers who 'lived irreproachable lives' such as Hobbes and Locke. Hume explains:

An epicurean or a Hobbist readily allows, that there is such a thing as friendship in the world, without hypocrisy or disguise, though he may attempt, by a philosophical chemistry, to resolve the elements of this passion, if I may so speak, into those of another, and explain every affection to be self-love, twisted and moulded, by a particular turn of the imagination, into a variety of appearances. (Hume 1970, 296-7)

Unlike Butler, Hume maintains that Hobbes acknowledged the occurrence of benevolence and friendship 'without hypocrisy or disguise' among men, but turned - by means of 'a philosophical chemistry' - all other-regarding feelings into self-love, namely a principle that explains everything but predicts nothing. Granted that both killing and saving lives can be interpreted in terms of self-love, will people kill or save lives in the state of nature?

The 'philosophical chemistry' by which Hobbes explained benevolent action as an instance of self-love is illustrated by John Aubrey's well-known anecdote:

One time, I remember, going into Strand, a poor and infirm old man craved his alms. He beholding him with eyes of pity and compassion, put his hands in his pocket, and gave him 6d. Said a divine (that is Dr Jasper Mayne) that stood by- 'Would you have done this, if it had not been Christ's command?' 'Yes,' said he. 'Why?' said the other. 'Because,' said he, 'I was in pain to consider the miserable condition of the old man; and now my alms, giving him some relief, doth also ease me.' (Aubrey 1975, 158-9) 
Hume seems to attribute to Hobbes something close to what Gert and others have termed 'tautological egoism', which resembles psychological egoism but is different in one fundamental respect: while psychological egoism holds that man always pursues his desires 'as opposed to the desires of someone else' and thus denies benevolent action, tautological egoism maintains that man always pursues his desires, but these desires are not 'opposed to anything' (Gert 1969, 111; see also Gert 1972, 6-7) and may very well include benevolent and conscientious action (Gert 1972, 9). Another way of drawing the distinction between the two positions can be found in Rawls ${ }^{1}$ who contrasts 'desires in a self':

(i) Self-centered desires: those for my own honor, power, glory; health and nourishment.

(ii) Self-related desires: for the honor and power of persons and groups related to me - my family, my friends, my nation, etc. (Rawls 2007, 445)

with 'desires of a self':

Affections for others are neither self-centred nor self-related desires: they include desires for the other's good. Proper self-love is an affection for our good and is altogether different from selfishness (Rawls 2007, 445)

For Rawls, selfishness (and psychological egoism) is related to self-centred and self-related desires and is to be distinguished from self-love proper (and tautological egoism).

To sum up, according to Butler, Hobbesian men are incapable of genuine benevolence; according to Hume, Hobbes accepts that men are capable of benevolence without hypocrisy, but ultimately Hobbes explains - not unlike a long tradition of philosophers before him - all actions of all men, be they heroes or cowards, benefactors or misers, as instances of self-love. If we accept the above definitions of psychological and tautological egoism, we can see that Butler attributed to Hobbes the former, while Hume hinted at the latter. A number of interpreters have found tautological egoism in Hobbes's argument, and have emphasised that egoism so understood is unfalsifiable (Watkins 1965) and a truism (Kavka 1986). Gert 
himself did not deny that Hobbes was a tautological egoist but strongly rejected the view that Hobbes endorsed psychological egoism (Gert 1969, 111; Gert 1972, 7). During the twentieth century, one of the liveliest debates in Hobbes studies has been about the occurrence and character of egoism in Hobbes's theory; here I am concerned with the appraisal of benevolent action which has been part of the wider debate on egoism.

\section{The Impossibility of Disinterested Benevolence}

The attribution of egoistic psychology to Hobbes goes back to his own times; indeed, the repudiation of Hobbes's arch-egoist was the aim of many commentaries (Mintz 1962). But it was Bishop Butler's understanding of Hobbesian psychology that was particularly influential on the scholarship of the best part of the last century (Taylor 1938, Gert 1967; Sorell 1986). In 1886 George Croom Robertson highlighted the merits of Butler's psychological analysis (221) and endorsed his reading of Hobbesian human nature, even if he defended Hobbes's intentions:

It has hardly remained in serious question since that there is a principle of properly disinterested action in the human system, and that Hobbes, if he had good reason for dwelling upon the might of the selfish tendencies in man and showed true psychological insight in tracking them through the transformations they assume, gave an essentially one-sided and distorted view of human activity. What his opponents, in their contention, never did him justice to remember, was that, if he did exaggerate or bring exclusively into view the egoistic impulses in man, it was yet in order to bar out their anarchic consequences by the most effective agency of which he could think (Robertson 1886, 221-2).

Robertson attributed to Hobbes a 'conception of man as moved by purely selfish impulses' (Robertson 1886, 135) and noted that in his writings, Hobbes 'can forget egoistic feeling' only rarely (Robertson 1886, 136) as when he acknowledges that people are capable of putting a 'certain nobleness or gallantness of courage' above personal contentment (Leviathan, Ch XV. 10 Curley p 93). 
In 1904 Leslie Stephen put across a similar view and drew attention to Hobbes's statements on charity, love, and laughter in Elements in order to support the claim that Hobbes ruled out genuine benevolence. For Stephen, Hobbes 'is the most thoroughgoing of egoists' that 'not only admits the universality of self-love, but speaks as though this were one of the obvious truths which require no proof or explanation' (Stephen 1904, 131). According to Stephen, for Hobbes 'to love men means that we think of them as useful' (Stephen 132); charity, good will, and parental love are 'a modification of the desire of power' (132) and friendship is a relationship purchased by contract (133). Stephen stresses 'the uncompromising egoism' endorsed by Hobbes (141) and remarks:

He was perfectly content to profess the most unblushing egoism and carry it out consistently. His essential aim was to be scientific, to accept the obvious facts, and to carry out the conclusions logically. His nominalism naturally went with individualism. Each man obviously is a separate thing which must be explained by its own properties, and not by reference to any mysterious bond of unity with other things....Finally, his thorough materialism seems to make the assumption of selfishness inevitable (Stephen 1904, 143)

Writing in 1938, A. E. Taylor emphasised the influence of Bishop Butler's interpretation of Hobbesian psychology 'from his day to our own':

When Butler set himself to expose the fallacies of the "selfish" psychology of human action, he found admirable examples of them in some of Hobbes's analyses of the 'passions', and he did the work of refutation so thoroughly that he has perhaps made the notion that there is nothing in Hobbes but this "selfish psychology" (a charge which he himself is careful never to make) current from his day to our own' (Taylor [1938] 1969, 36).

Taylor does not seem wholly convinced by Butler's reading; however, he makes his famous case for the existence in Hobbes's theory of 'a very strict deontology' by stressing that the latter is 'disengaged from an egoistic psychology with which it has no logically necessary connection' $(1969,36-7)$. 
In 1967, Bernard Gert denounced as 'almost unanimous' the reading of Hobbes as a theorist of 'psychological egoism' in Hobbesian scholarship; indeed, Gert presented his thesis that Hobbes did not hold an egoistic view of man as 'original' ([1967] 1969, 109).

On the one hand, it is true that the attribution of the terms 'egoistic', 'egotistic', and 'egocentric' to Hobbes's description of man occurs throughout the twentieth century in otherwise very different interpretations of Hobbes's theory:

[The Hobbesian Man is] calculating, egotistic, and alone even in society (Wolin 1960, 246)

Hobbes's theory of human nature [...] yields a uniformity-principle and also what may be called an egocentricity-principle (Watkins 1965, 71-72).

Hobbes sees a rather large degree of ruthless egocentricity as a general human trait. (Spragens 1973, 103-4)

Hobbes veers between the notion that the individual is an animate solipsis ... and the view that he is merely selfish and egoistic... Man is not alone, but he carries an island within himself (King 1974, 191)

Hobbes does not deny that many will reject his conception of man. Men will want to argue that ...men are in fact capable of sincere, honourable, selfless compassion for other men. What Hobbes maintains is that the very actions and behaviour of his doubters "disavow what their discourses approve of". The natural axiom of human behaviour is nothing more than that man, by natural necessity, desires his own good and shuns whatever is destructive of his well-being. All behaviour is egoistic, necessarily self-interested. ... Every man seeks the society of others for his own benefit, not theirs. (Herbert 1989, 114, 115)

On the other hand, it is often unclear whether interpreters who ascribed egoism to Hobbes meant psychological egoism or tautological egoism, or if they understood psychological egoism in Gert's sense or in a broader sense. ${ }^{2}$ Leaving labelling aside, interpreters brought to bear on the debate about the egoism of the Hobbesian man a number of arguments, and here I survey a few that are relevant for my focus on benevolence.

It has been argued that egoism is an essential component of Hobbes's argument about the state of anarchy which in turn provides the foundation for his political and moral theory; Hobbes's equation of life and desire and his emphasis on the paramount importance of self- 
preservation made egoism inevitable (Herbert 1989), as did his claim that the right of selfdefence is inalienable (McNeilly 1968). It has been pointed out that a requirement of Hobbes's political theory is to assume uniformity of human nature and commonality of motivation; for Hobbes to admit that there are significant differences in motivation among people, 'would have been fatal to his project of a political system deduced from universal psychological principles' (Watkins 1965, 259). Nominalism has also been invoked to support the claim that Hobbes believed in commonality of motivations: it drove him to consider only what makes men resemble one another and not how they differ (Stephen 1904, Watkins 1965). If Hobbes had assumed that men are similar only in certain respects, this would have caused problems for his nominalism, as it would have come 'dangerously close to conceding that a universal name was imposed because they share certain universal properties - the end of the thesis that "there is nothing in the world universal but names"' (Watkins 1965, 259).

Above all, interpreters have drawn attention to mechanistic materialism in providing Hobbes with reasons for regarding men as self-maintaining engines of identical design, who cannot have other-regarding aims. While Robertson had strongly denied the connection between Hobbes's 'selfish' psychology and his metaphysics (1886, 135), a long string of interpreters have seen in Hobbes's mechanistic theory the foundation of his psychological egoism:

[S]ince the vital motions of the heart can only be excited by the prospect of some bodily change in its owner, all motivation is essentially egocentric (Watkins, 1969 p97 italics in the original)

From this account of vital and voluntary motion, it follows that each man seeks, and seeks only, to preserve and to strengthen himself. A Concern for continued well-being is both the necessary and the sufficient ground of human action. Hence man is necessarily selfish. (Gauthier 1969, 7)

To conclude, during the last century a significant number of interpreters have argued that Hobbes assumed the egocentricity or self-interestedness of man and ruled out the occurrence 
of disinterested benevolence because of the requirements of his political theory, his nominalism, and his mechanical materialism.

\section{The Uncommonness of Disinterested Benevolence}

In 1967, Gert denounced the almost unanimous consensus among scholars in attributing to Hobbes an egoistic view of human nature; in 1987, Gary Herbert highlighted the opposite phenomenon, namely the 'interpretative dismissal of Hobbes's notorious "egoism" by many recent scholars' (Herbert, 1987, 86). Indeed, in the second half of the twentieth century we encounter a new trend in Hobbes studies that rejects the attribution of narrow psychological egoism to Hobbes, drawing particular support from Leviathan.

[T] he account of the passions in Leviathan ... is not predominantly egoistic, although an unambiguously egoistic account is given in other works. (McNeilly 1968, 95)

Nothing in Hobbes's theory requires that men not have friends for whom they are willing to make some sacrifice. (Gert, 1972, 8)

If psychological egoism holds that people never act to benefit others, then Hobbes was never a psychological egoist. (Sorell 1986, 98)

Why does [Hobbes] flirt with motivational reductionism even though, as I have amply documented, his portrait of the human psyche is actually rich and unparsimonious? (Holmes, 1990, 144)

Hobbes does not say in the Leviathan that people are psychological egoists, or that they pursue or care only about their own good. (John Rawls 2007, 45)

Hobbes's texts will not bear interpreting him as espousing psychological egoism. (S.A. Lloyd, 2009, 79; see also Lloyd 1992, chapter 4, 158-166)

Over several decades, Bernard Gert led the camp that rejected the claim that psychological egoism occurs in or is needed by Hobbes's political theory (Gert 1967; 1972, 2010). Interpreters contended that Hobbes changed his views about the passions over time and that the charge of psychological egoism is not applicable to Leviathan (McNeilly 1968); they refuted Butler's interpretation of Hobbes's concepts of pity, charity and love (Sorell 1986); they drew attention to the multiple sources of identity of Hobbesian men and to the crucial 
role attached by Hobbes to education (Sorell 1986, Lloyd 1992, 2009). Nominalism was now being used to support the claim that Hobbes believed men to be different from one another; the well-known quote about self-inspection ${ }^{3}$ was now being invoked to emphasise the different contents of the passions in different men. Scholars opposed the view that in Leviathan we encounter a 'prototype man' and spoke of different models of man (Johnston 1986) or no model of man (Slomp 2000); they argued that Hobbes's psychology is more complex and nuanced that some quotations would suggest (Holmes 1990); they rejected the idea that Hobbesian men see others only as means to attain their ends (Baier 1987, Stanlick 2002); they challenged the notion that natural men and citizens are the same (Gert 1972, 11; 2010); they questioned Gauthier's suggestion that in biology a selfish principle must give rise to selfish behaviour.

S.A. Lloyd drew attention to 'transcendent' interests - including moral and religious interests - that override fear of death and that are different in different men (1992) and argued that Hobbesian men are capable of other-regarding interests and benevolence $(2009,79)$ :

the notion of transcendent interests enables us to distinguish between a merely "tautological" egoism and the robust psychological egoism in dispute in Hobbes studies. A tautological egoism could incorporate transcendent interests. Hobbes's recognition that people can hold transcendent interests in things other than states of themselves speaks against interpreting him as espousing psychological egoism. (Lloyd 2012, 126)

John Rawls not only found benevolence in Leviathan:

[Hobbes] does say in Chapter VI that we are capable of benevolence; of desire of good to another; of good will; and of charity...He says that we are capable of loving people, and in Chapter XXX, he ranks conjugal affections as second in importance after our own self-preservation and before the means of a commodious life...He therefore does think that people are capable of benevolence and of genuine affection for other people, or concern for their good (Rawls 2007, 45).

but also suggested that for Hobbes the three 'fundamental interests' of civil societies in order of importance are: 
Our interest first in preserving our life, then our interests in securing the good of those who are close to us (what Hobbes calls 'conjugal affection'), and finally, our interest in acquiring the means of a commodious life. (Rawls 2007, 46)

To conclude, in the last forty years the rejection of Butler's reading of Hobbesian benevolence developed from a minority position to the mainstream view in Hobbes studies.

There is broad consensus that Hobbes acknowledged that men are capable of other-regarding feelings but nevertheless regarded disinterested benevolence as uncommon, altruism as exceptional, and that he considered men as generally inclined to look after themselves first and foremost. Edwin Curley voiced a wide-spread opinion when he wrote:

Hobbes does not deny the existence of benevolent or conscientious actions, and he probably does not think that they always have an ulterior motive, though he is apt to see self-interest in any act of charity. But he certainly thinks that disinterested benevolence and action for the sake of duty are uncommon enough that political theory should not take much account of them. (Curley 1994, XV)

The Inconveniences of Benevolence

The long-standing scholarly debate on the possibility of genuine Hobbesian benevolence is a direct consequence of Hobbes's ambivalent remarks on the issue. Why was Hobbes so hesitant to take a clear position? Here I argue that Hobbes maintained that all benevolence (self-interested or disinterested as it may be) is a potential inconvenience to the commonwealth and therefore the question of whether men are capable of benevolent action is politically irrelevant.

To begin with, it is worth reminding ourselves of Hobbes's definition of benevolence. In Leviathan, Hobbes distinguishes 'benevolence' from 'good nature' and defines the former as 'love of others' and the latter as 'love to man generally' (Leviathan VI. 22); he also differentiates benevolence from 'love of one singularly, with desire to be singularly beloved, The Passion of Love' (VI. 33). ${ }^{4}$ The distinction Hobbes draws between 'love of others', 'love 
to man generally' and 'love of one singularly' shows that Hobbes understands benevolence as the love of some others. Thus, Hobbesian benevolence is selective: it includes some particular men and excludes the rest. In spite of his reference to 'love to men generally' in Leviathan (VI.22, 'love to men generally' does not occur in OL), there is agreement among scholars (e.g. Sorell 1986, Gert 1972) that Hobbes ruled out universal benevolence and rejected the idea that we love people because they are members of mankind. Hobbes writes,

For if man naturally loved his fellow man. Loved him, I mean, as his fellow man, there is no reason why everyone would not love everyone equally as equally men (Citizen, I.2).

Hobbes suggests that the recipients of benevolence - the 'others' that people are inclined to love - are family and friends: 'the nearest by nature are supposed to be nearest in affection' (Citizen, IX, 18, p114). He indicates that we cannot be benevolent to strangers:

The affection wherewith men many times bestow their benefit on strangers, is not to be called charity, but either contract whereby they seek to purchase friendship, or fear, which maketh them to purchase peace. Elements, I. 9.17

Why did Hobbes rule out universal benevolence? The answer is not to be found in Hobbes's nominalism ${ }^{5}$ but rather in his understanding of human nature. In the well-known comparison between the behaviour of bees, ants, and men that occurs in all three political writings, Hobbes emphasises the desire of glory and the natural partiality of man:

Why therefore may not men, that foresee the benefit of concord, continually maintain the same without compulsion, as well as they [bees]? To which I answer, that amongst other living creatures, there is no question of precedence in their own species, nor strife about honour or acknowledgement of one another's wisdom, as there is amongst men;... Secondly, those living creatures aim everyone at peace and food common to all; men aim at dominion, superiority, and private wealth, which are distinct in every man and breed contention. Elements I. 19. 5, p102

In the first place, men compete for honour and dignity, animals do not...Secondly, the natural appetites of bees and similar creatures are uniform, and make for the common good, which among them does not differ from private good; but for man virtually nothing is thought to be good which does not give his possessor some superiority and eminence above that enjoyed by other men. Citizen V.5 p 71 
First, ...men are continually in competition for honour and dignity, which these creatures are not;... Secondly, that among these creatures, the common good differeth not from the private; and being by nature inclined to their private, they procure thereby the common benefit. But man, whose joy consisteth in comparing himself with other men, can relish nothing but what is eminent. Leviathan XVII, 7- 8, Curley 108

To a man nothing is so pleasant in his own goods as that they are greater than those of others $O L$ Curley 108

Because of his desire of glory and of his partiality, the Hobbesian man is disinclined to develop universal love: Hobbesian benevolence, in either selfless or selfish form, is not just selective but exclusionary and potentially divisive. In Hobbes's account, benevolence or love of some others can undermine the commonwealth: officials may be enticed to bend rules for their loved ones; judges may be tempted to show preference to family and friends. For Hobbes, what makes a good judge is the ability to divest himself not only of 'all fear, anger, hatred' but also of 'love, and compassion' (Leviathan XXVI, 28). Hobbes argues that a major reason why democracy is inferior to monarchy as form of government is the fact that the many individuals who make up an assembly have more people they care about and want to help:

And though [the sovereign] be careful in his politic person to procure the common interest, yet he is more, or no less, careful to procure the private good of himself, his family, kindred and friends; and for the most part, if the public interest chance to cross the private, he prefers the private: for the passions of men are commonly more potent than their reason. From whence it follows that where the public and private interest are most closely united, there is the public most advanced (Leviathan XIX, 4)

And whereas the favourites of monarchs are few, and they have none else to advance but their own kindred; the favourites of an assembly are many, and the kindred much more numerous than of any monarch. Leviathan, XIX, 8 Curley p 121.

So, for Hobbes, benevolence - as a form of partiality which may motivate iniquity and corruption - is potentially dangerous for the commonwealth: it can prejudice justice, subvert fairness, and jeopardise peace. The laws of nature recommend universal sociability and kindness and rule out special treatment for family and friends, whether motivated by genuine 
love or self-interest. For Hobbes, it is 'arrogance' and contravenes the laws of nature for the sovereign to favour undeserving relatives or friends: 'sovereigns are obliged by natural law to impose the burdens of the commonwealth upon the citizens equally' (Citizen XIII. 10, p. 147). The sovereign should never patronise anyone out of personal like or dislike; the only grounds for different treatment of subjects and the distribution of rewards must be the enhancement of the common good (Leviathan XXX.24, Curley p. 230). Indeed, to rulers and officials:

"Natural law commands: in awarding rights to others, you should be fair [aequalis] to both sides... This law forbids us from giving more or less to one person as a favour." Citizen III.15 p. 50, emphasis added.

From a Hobbesian perspective, the more personal relationships of love and affection there are between officials, rulers, and the people, the more sources of partiality and iniquity there may be, and the more vulnerable the commonwealth may become.

As Hobbes adopted the impact on peace as his criterion to distinguish between virtue and vice, and maintained that "good dispositions are those which are suitable for entering into civil society; and good manners (that is moral virtues) are those whereby what was entered upon can be best preserved," (De Homine XIII, p70 emphasis added) it is no surprise that he did not regard benevolence as a virtue. Benevolence in either its selfless or selfish form may foster partiality and compromise concord ${ }^{6}$, unlike justice and equity which consolidate peace and are therefore moral virtues (De Homine XIII, p 69). Just as Hobbes did not regard courage, prudence and temperance as virtues because they may be harmful to the state ( S.A. Lloyd 2009, $140-1^{7}$ ), likewise he warned about the effects of benevolence on the commonwealth.

Whether officials, judges, members of democratic assemblies or any others are driven to bend rules for their families and friends out of self-interest or out of genuine generosity is ultimately irrelevant in so far as their actions are equally damaging to the political state. From 
the point of view of the good of the commonwealth, the self-interested merchant, who pays his taxes, obeys the law, is mean to family and friends, and never helps anyone unless there is something for him to gain is a better citizen than the big-hearted official who is willing to put his job on the line and flout protocol in order to help a worthy relative or friend in need.

Not unlike egoists, Hobbesian benefactors (selfless or selfish as they may be) are prone to misunderstanding the real good of their beneficiary: they can see only the immediate, apparent benefits and are blind to long-term harms. Officials, for instance, fail to understand that by bending rules to help family and friends they undermine the state and by so doing endanger the conditions of the wellbeing of their loved ones. Many interpreters have pointed out that Hobbes's distinctions between apparent and real good, and between immediate and long-term good, shed light on his appraisal of benevolent action. Hobbes writes:

Moreover, good (like evil) is divided into real and apparent. Not because any apparent good may not truly be good in itself, without considering the other things that follow from it; but in many things, whereof part is good and part evil, there is sometime such a necessary connection between the parts that they cannot be separated. Therefore though in each one of them there be so much good, or so much evil; nevertheless the chain as a whole is partly good and partly evil..... Whence it happens that inexperienced men that do not look closely enough at the long-term consequences of things, accept what appears to be good, not seeing the evil annexed to it; afterwards they experience damage. (De Homine, XVI, 48)

The way forward for Hobbes is not to condemn egoism and to encourage altruism in men as preachers may do, because benevolence - be it self-interested or disinterested - is often misguided. Rather, the political philosopher needs to provide enlightenment on the conditions of peace and on the real long-term good of self and other.

\section{Conclusion}

This paper started with the observation that Hobbes seems to be of two minds about benevolence and that this ambivalence has given rise to a long-standing debate on whether 
the Hobbesian individual is capable of genuine benevolent action. I reviewed in broad outlines two different positions: one, expounded by Butler, according to which Hobbesian men are fundamentally selfish and incapable of disinterested love; the other (that can be found in Hume) which holds that Hobbes did believe that men are capable of genuine love and benevolence, but explained all acts as instances of self-love. I have suggested that these two positions developed in the twentieth century, with the supporters of the latter view gaining ground during the last few decades. I then put forward the claim that Hobbes did not regard benevolence in either form (selfish or selfless) as necessarily good for peace. I have argued that Hobbesian benevolence is not only selective, but exclusionary and potentially divisive for the commonwealth. I have contended that for Hobbes the distinction between self-interested and selfless benevolence is politically irrelevant because ignorant men, be they egoists or otherwise, will always damage the wellbeing of the commonwealth. From Hobbes's perspective, well-meaning benefactors are as ignorant as self-serving egoists about the real 'good' of their loved ones and may engage in activities that undermine concord and peace. Only understanding, according to Hobbes, can help to establish, maintain and strengthen concord and peace, and prevent misguided benevolence as much as ill-advised selfishness. Indeed, if all Hobbesian men were to transform overnight from self-interested into altruistic citizens, but remained ignorant about everyone's real good, then there would be no reason to think that they would not still compromise the safety and wellbeing of their commonwealth.

\section{REFERENCES}

Aubrey, John. 1982. Brief Lives. Ed: Richard Barber. Woodbridge: The Boydell Press. Baier, Annette C. 1987. “Commodius Living." Synthese 72(2): 157-85. 
Butler, Joseph. 1726 'Upon Human Nature' Sermon 1 from Fifteen Sermons Preached at the Rolls Chapel, reprinted in Bernard H. Baumrin (1969) (Ed) Hobbes's Leviathan:

Interpretation and Criticism. Belmont California: Wadsworth Publishing, pp 16- 25,

Curley, Edwin 1994. 'Introduction' Leviathan with selected variants from the Latin edition of 1668. Ed: Edwin Curley. Indianapolis: Hackett Publishing, pp VIII-XLVII.

Gauthier, David (1969) The Logic of Leviathan: The Moral and Political Theory of Thomas Hobbes. Oxford: Clarendon Press

Gert, Bernard. 1967. "Hobbes and Psychological Egoism." Journal of the History of Ideas 28(4): 503-20; reprinted in Bernard H. Baumrin (1969) (Ed) Hobbes's Leviathan: Interpretation and Criticism. Belmont California: Wadsworth Publishing, 107-126.

Gert, Bernard. 1972.'Introduction' Man and Citizen. Thomas Hobbes's De Homine and De Cive also known as Philosophical Rudiments Concerning Governments and Society, 232

Gert, Bernard. 2010. Hobbes: Prince of Peace. Cambridge: Polity.

Herbert, Gary 1989 Thomas Hobbes: The Unity of Scientific \& Moral Wisdom. Vancouver: University of British Columbia Press.

Holmes, Stephen. 1990. 'Political Psychology in Hobbes's Behemoth' in Thomas Hobbes \& Political Theory. Ed Mary Dietz. Lawrence, Kansas: University Press of Kansas, pp.120-152

Hume, David. 1970. Enquiries Concerning the Human Understanding and Concerning the Principles of Morals. Reprinted from the posthumous edition of 1777. Edited by L.A. SelbyBigge. Second edition.

Johnston, David. 1986.The Rhetoric of Leviathan. Princeton: Princeton University Press.

Kavka, Gregory. 1986. Hobbesian Moral and Political Theory. Princeton: Princeton University Press.

King, Preston. 1974. The Ideology of Order: a Comparative Analysis of Jean Bodin and Thomas Hobbes. London: George Allen \& Unwin

Lloyd, S. A. 1992. Ideals as Interests in Hobbes's Leviathan: The Power of Mind over Matter. Cambridge: Cambridge University Press.

Lloyd, S.A. 2009. Morality in the Philosophy of Thomas Hobbes. Cases in the Law of Nature Cambridge: Cambridge University Press.

Lloyd, S.A. 2012. 'Egoism' in The Bloomsbury Companion to Hobbes. Ed: S.A. Lloyd London: Bloomsbury, 125-127.

McNeilly, FS. 1968. The Anatomy of Leviathan. London: Macmillan St Martin Press

Mintz, Samuel I. 1970. The Hunting of Leviathan: Seventeenth century Reactions to the Materialism and Moral Philosophy of Thomas Hobbes. Cambridge: Cambridge University Press. 
Nagel, Thomas 1970 The Possibility of Altruism Oxford: Clarendon Press

Rawls, John. 2007. Lectures on the History of Political Philosophy, ed. Samuel Freeman. Cambridge, MA, and London: Harvard University Press.

Robertson, George Croom. 1886. Hobbes Edinburgh: Blackwood and Sons

Slomp, Gabriella. 2000. Thomas Hobbes and the Political Philosophy of Glory. Houndsmill: Macmillan.

Slomp, Gabriella. 2018. “As Thick as Thieves: Exploring Thomas Hobbes's Critique of Ancient Friendship and its Contemporary Relevance", forthcoming.

Sorell, Tom. 1986. Hobbes. London: Routledge \& Kegan Paul

Spragens, Thomas A. 1973. The Politics of Motion: The World of Thomas Hobbes. With a Forward by Anthony Flew. London: Croom Helm.

Stanlick, Nancy. 2002. "Hobbesian Friendship: Valuing Others for Oneself”. Journal of Social Philosophy, vol 33(3): 345-59

Stephen, Leslie 1904 Hobbes London: Macmillan \& Co

Taylor, A.E. 1938. 'The Ethical Doctrine of Hobbes'. Philosophy, vol XIII, 406-424 reprinted in Bernard H. Baumrin (1969) (Ed) Hobbes's Leviathan: Interpretation and Criticism. Belmont California: Wadsworth Publishing, pp35-48

Watkins, John W. N. (1969) Philosophy and Politics in Hobbes in K.C Brown (Ed) Hobbes Studies Oxford: Basil Blackwell, 237-262 reprinted in Bernard H. Baumrin (1969) (Ed) Hobbes 's Leviathan: Interpretation and Criticism. Belmont California: Wadsworth Publishing, pp83-106

Watkins, John W. N. (1965 ) Hobbes's System of Ideas. London: Hutchinson

Wolin, Sheldon 1960 Politics and Vision. Continuity and Innovation in Western Political Thought Princeton: Princeton University Press.

${ }^{1}$ I owe this reference to S.A.Lloyd. 
${ }^{2}$ For instance, Tom Sorell rejected the view that there is psychological egoism in Gert's sense in Hobbes's works, but suggested that 'egoism may be the right label for Hobbes's position if the term is defined broadly enough' (Sorell, 1986, 99). For Sorell a definition of egoism that is 'wide enough' to accommodate Hobbes's statements about self-interest and his concessions to limited benevolence is Nagel's: 'Egoism holds that each individual's reasons for acting, and possible motivations for acting, must arise from his own interests and desires, however those interests may be defined. The interests of one person can on this view motivate another or provide him with a reason only if they are connected with some sentiment of his, like sympathy, pity or benevolence' (Nagel, 1970, 84, cited also by Sorell 1986, 99).

${ }^{3}$ 'But there is another saying not of late understood, by which [men]might learn truly to read one another, if they would take the pains; and that is , nosce teipsum, read thy self, [which was meant ] to teach us that for the similitude of the thoughts and passions of one man to the thoughts and passions of another, whosoever looketh into himself and considereth what he doth, when he does think, opine, reason, hope, fear, \&c, and upon what grounds; he shall thereby read and know what are the thoughts and passions of all other men upon the like occasions. I say the similitude of passions, which are the same in all men, desire, fear, hope, \&c.; not the similitude of the objects of the passions, which are the things desired, feared, hoped, \&c; for these the constitution individual, and particular education, do so vary, and they are so easy to be kept from our knowledge, that the characters of man's heart, blotted and confounded as they are with dissembling, lying, counterfeiting, and erroneous doctrines, are legible only to him that searcheth hearts'. (Leviathan, Introduction [3]; Curley p 4; italics in the original). 
Supporters of the 'uniformity of human nature' thesis have often quoted only the first part of Hobbes's remark (e.g. Watkins 1969, 104 ), while critics of the uniformity thesis have tended to draw attention only to the second part.

${ }^{4}$ In the same chapter Hobbes also distinguishes benevolence from 'Love of persons for society, Kindness'; 'Love of persons for pleasing the sense only, natural Lust'; ' Love of the same acquired from rumination, that is, imagination of pleasure past, Luxury'.

${ }^{5}$ Driven by his nominalism, Hobbes thought that we can love Peter and Elspeth, John and Kirsten; we can even love the King, but we cannot love 'man', 'mankind', or the 'citizenry' because we cannot love universals which are just names. His nominalism, however, did not rule out the possibility of loving every single individual in one's community. I owe this comment to S.A.Lloyd.

${ }^{6}$ I discuss this claim in relation to Hobbesian friendship in "As Thick as Thieves: Exploring Thomas Hobbes's Critique of Ancient Friendship and its Contemporary Relevance”, forthcoming •

7 'The Laws of nature articulate moral virtues, and moral virtues are the dispositions that create and sustain civil society, that is the commonwealth-based form of life requisite for peaceful, sociable, and comfortable living. Rational excellences that contribute to the interests of the agent but not reliably to the interests of the collective... are neither moral virtues nor among “the” Laws of nature Hobbes enumerates'. (Lloyd 2009, 141) 